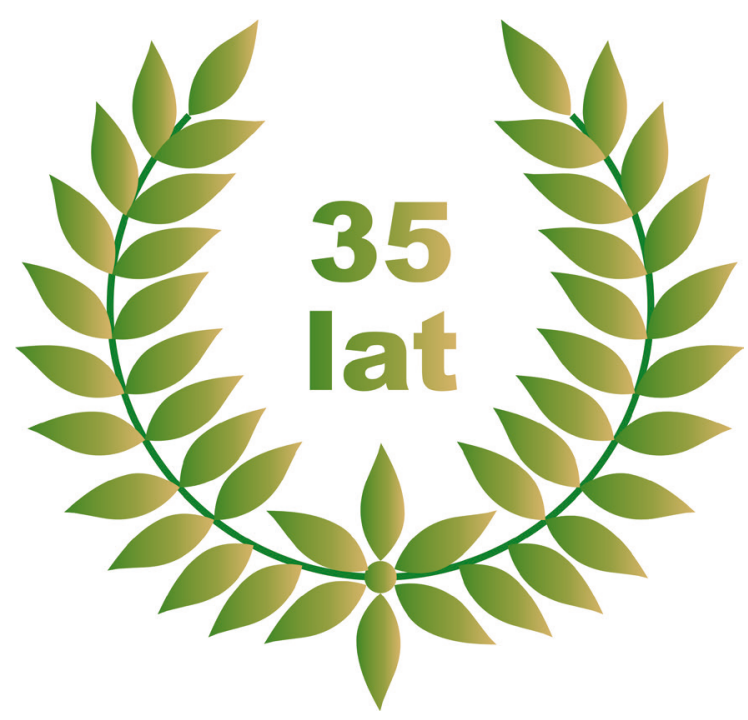

\title{
35 LAT CZASOPISMA „TURYZM/TOURISM”
}

Historia słowa „,turyzm” w języku polskim sięga okresu międzywojennego. Do obiegu naukowego wprowadził je profesor Uniwersytetu Jagiellońskiego Stanisław Leszczycki (1907-1996), który w 1937 r. zdefiniował to pojęcie jako „,całokształt zagadnień turystycznych, gospodarczych, geograficznych, statystycznych, prawnych, kulturalnych i społecznych związanych z ruchem uzdrowiskowo-turystycznym" (Wprowadzenie, 1985, s. 3). Już wtedy turystyka była postrzegana w Polsce jako złożone, wieloaspektowe zagadnienie badawcze.

Do tradycji tych nawiązano w latach 70. XX w., kiedy - w zupełnie już innych realiach społeczno-politycznych (kraj socjalistyczny z gospodarką centralnie sterowaną) - reaktywowano badania naukowe nad zjawiskiem turystyki (prowadzili je głównie geografowie, ale też przedstawiciele innych dyscyplin naukowych). W 1979 r. na Uniwersytecie Jagiellońskim powstał pierwszy w kraju Zakład Geografii Turyzmu. Jego twórcami byli autorzy pionierskiego podręcznika pt. Podstawy geografii turyzmu (Warszyńska, Jackowski, 1978). Równolegle na Uniwersytecie Łódzkim rozpoczęto kształcenie $\mathrm{w}$ zakresie turystyki najpierw w ramach Podyplomowego Studium Turystyki, a potem specjalizacji na studiach geograficznych w utworzonym w $1981 \mathrm{r}$. przez prof. Stanisława Liszewskiego Zakładzie Geografii Miast i Turyzmu.

Badania nad turystyką prowadzone były w tym czasie także w wielu innych ośrodkach akademickich w Polsce (Wrocław, Warszawa, Poznań, Gdańsk). Powstajace coraz liczniej prace naukowe nie zawsze jednak było gdzie opublikować. W kraju istniało zaledwie kilka czasopism poświęconych problematyce turystycznej, jednak niekoniecznie ukazywały się one systematycznie, a możliwości publikacji artykułów w zagranicznych periodykach były bardzo ograniczone $z$ powodu istnienia tzw. żelaznej kurtyny. Dotkliwie brakowało forum wymiany wyników badań, poglądów i teorii naukowych związanych z turystyką.

Lukę tę dostrzegł założyciel Zakładu Geografii Miast i Turyzmu UŁ S. Liszewski i w 1985 r. w ramach zeszytów naukowych „Acta Universitatis Lodziensis” powołał nowe czasopismo pt. „Turyzm”. Nazwa nawiązywała do czasopisma „Turyzm Polski”, założonego przed II wojną światową przez wspomnianego S. Leszczyckiego, i miała upamiętniać tego uczonego jako pioniera badań nad turystyką. 
Łamy nowo utworzonego czasopisma z założenia miały być udostępnione wszystkim badaczom turystyki, niezależnie od reprezentowanej przez nich dyscypliny. Wynikało to z zapożyczonej od S. Leszczyckiego definicji turyzmu, podkreślającej interdyscyplinarny charakter badań, oraz z przyjętego założenia, że teorię turystyki można rozwijać tylko przy udziale badaczy wielu dyscyplin naukowych. Do publikowania w utworzonych zeszytach zaproszono autorów zarówno prac empirycznych, jak i istotnych artykułów przeglądowych oraz oryginalnych prac teoretycznych, a także aplikacyjnych, mogących stanowić pomoc w ulepszaniu działalności praktycznej instytucji turystycznych.

Struktura pierwszych zeszytów „Acta Universitatis Lodziensis. Turyzm” obejmowała stałe działy, w których zamieszczano: artykuły, notatki naukowe, sprawozdania (najczęściej z przedmiotowych konferencji naukowych, ale także seminariów i ćwiczeń terenowych ze studentami) oraz recenzje publikacji. W dobie politycznej izolacji dla wielu polskich naukowców lektura sprawozdań z zagranicznych konferencji czy recenzji obcojęzycznych książek była jedyną możliwością śledzenia aktualnych zagadnień badawczych z zakresu turyzmu. Dlatego trudno przecenić rolę tych dwóch działów.

Początkowo zespół redakcyjny czasopisma „Acta Universitatis Lodziensis. Turyzm” był bardzo skromny - liczył zaledwie dwie osoby (S. Liszewski - redaktor, Elżbieta Dziegieć - sekretarz naukowy). Ambicją redakcji było zamieszczanie już od pierwszego numeru obszernych streszczeń artykułów w językach obcych, tłumaczonych przez stałych współpracowników z Wydziału Filologicznego UŁ: Lucjana Kowalskiego (język francuski) i Leszka Podbielskiego (język angielski). Zakładano bowiem, że „Turyzm” skierowany jest do szerokiego grona odbiorców, nie tylko rodzimych, ale również zagranicznych. W latach 1985-1990 w serii "Acta Universitatis Lodziensis. Turyzm" opublikowano 7 zeszytów w formacie B5 (w 1990 r. dwa zeszyty - 6 i 7) - rys. 1a i 1b. Znalazło się w nich łącznie 35 artykułów, 8 notatek naukowych, 10 sprawozdań i 7 recenzji.

W 1991 r. utworzono samodzielne czasopismo naukowe pt. Turyzm, ukazujące się dwa razy w roku, z nową numeracją (t. 1, z. 1; t. 1, z. 2 itd.). W Kolegium Redakcyjnym pracowały trzy osoby: S. Liszewski jako redaktor, E. Dziegieć - zastępca redaktora, i Elżbieta Paradowska - sekretarz czasopisma. Powołano też czteroosobową Radę Naukowa, w której składzie znaleźli się wybitni polscy specjaliści w dziedzinie turystyki: Jadwiga Warszyńska, Alicja Krzymowska-Kostrowicka, Antoni Jackowski i Jerzy Wyrzykowski.

W dziesięcioleciu 1991-2000 wydano 20 zeszytów w ramach 10 tomów, w których zamieszczono 83 artykuły, 39 notatek naukowych, 51 sprawozdań oraz 39 recenzji. Periodyk otrzymał nową formę i szatę graficzną (rys. 1c i 1d). Zachowano jednak dotychczasową strukturę, publikując działy: Artykuły, Notatki naukowe, Sprawozdania i Recenzje. W przypadku pięciu zeszytów wprowadzono jednorazowo nowe działy (np. Dyskusja, Informacje bibliograficzne, Notatki dydaktyczne), co wynikało z charakteru prezentowanych opracowań. Utrzymano też obszerne dwujęzyczne streszczenia, których tłumaczenia wykonywali L. Kowalski (język francuski) i Ewa Mossakowska (język angielski). W celu zapewnienia ujednoliconej oprawy kartograficznej i graficznej artykułów zatrudniono - pracującą w redakcji do dziś - Annę Wosiak.

Kolejne lata ukazywania się czasopisma „Turyzm” (2001-2008) przyniosły wiele istotnych zmian. Od 2001 r. realizowano obowiązek recenzji zewnętrznej artykułów i zamieszczania nazwisk recenzentów na stronie redakcyjnej. Równie ważnym posunięciem było wprowadzenie tłumaczenia pełnych wersji artykułów na język angielski. Wymusiło to zmianę formatu z B5 na A4, ponieważ postanowiono wprowadzić podział kolumny na dwa łamy, by teksty w języku polskim i angielskim mogły występować równolegle obok siebie. Jednocześnie zrezygnowano z tłumaczeń na język francuski. Od początku wieku aż do dziś o profesjonalny poziom języka angielskiego w tekstach naukowych dbają tłumaczka E. Mossakowska i native speaker Richard Bolt, z wykształcenia geograf. W tym czasie do Rady Redakcyjnej dołączył prof. Andrzej Matczak.

W okresie 2001-2008 wydano 14 zeszytów w ramach 8 tomów (dwa zeszyty były podwójne), w których zamieszczono 75 artykułów, 28 notatek naukowych, 17 sprawozdań i 28 recenzji. Mimo zastosowania nowego formatu periodyku, zachowano jego kolorystykę i elementy graficzne nawiązujące do poprzedników (rys. 1e). Zmianie uległa struktura artykułów: do celów bibliograficznych wprowadzono zarysy treści i słowa kluczowe w obu językach.

Lata 2009-2020 były czasem wprowadzania w czasopiśmie kolejnych znaczących zmian, które służyły przygotowaniu ,Turyzmu” do wejścia na rynek zagraniczny. Dwujęzyczne czasopismo, publikowane dotąd $\mathrm{w}$ dwóch równoległych łamach (co, niestety, okazało się niewygodne przy składaniu poszczególnych zeszytów), zostało gruntownie przekształcone. Postanowiono drukować obie wersje językowe jako odrębne całości, połączone wspólną odwróconą w stosunku do drugiej wersji językowej okładką (rys. 1f i 1g). Tym samym zaszła konieczność wprowadzenia dwóch tytułów i od 2009 r. czasopismo nosi nazwę „Turyzm/Tourism”. Od tego też roku rozpoczęto publikowanie periodyku w wersji angielskiej przez elektroniczne wydawnictwo naukowe Central European Science Publishers „Versita” (przejęte w 2014 r. przez De Gruyter Open EURSCI, a od 2018 r. prowadzone przez Sciendo). Publikowanie w Internecie wymagało nadania czasopismu numeru e-ISSN (2080-6922 - od 2009 r.), a zamieszczanym w nim artykułom - numerów DOI. Od 2016 r. wersja online jest 

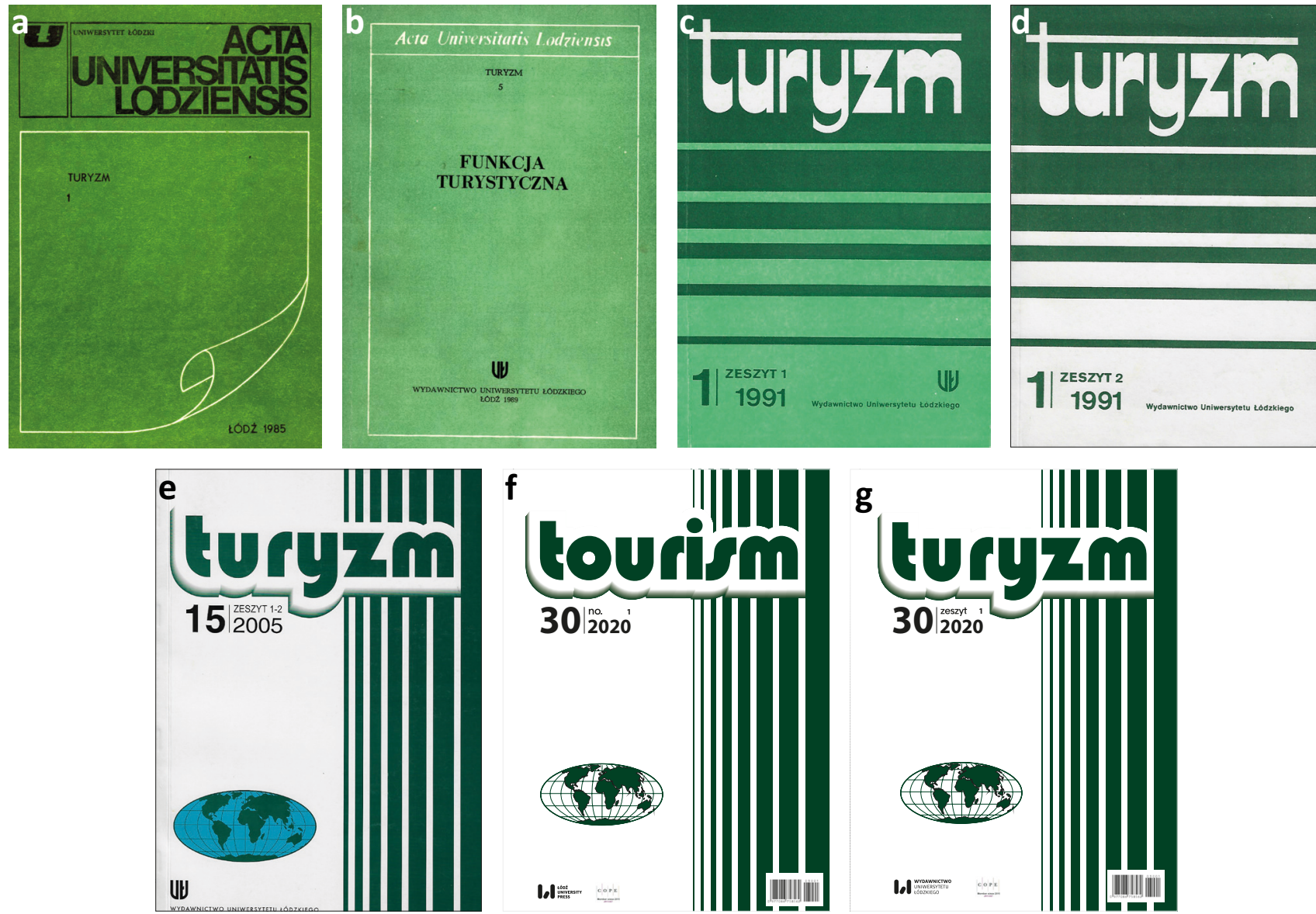

Rysunek 1. Okładki czasopisma „Turyzm/Tourism” od 1985 do 2020 r. Źródło: archiwum własne

wersją pierwotną. Ogółem w latach 2009-2020 w 12 tomach ukazało się 170 artykułów, 11 notatek naukowych, 9 sprawozdań i 16 recenzji.

Ważnym przedsięwzięciem było wprowadzenie w 2009 r. obowiązku poddawania artykułów ocenie dwóch recenzentów w systemie double-blind peer review. Umiędzynarodowiono też Radę Naukową czasopisma - do pięciu polskich członków dołączyło pięciu zagranicznych naukowców. Niestety również w tym roku zmarła pełniąca obowiązki zastępcy redaktora naczelnego E. Dziegieć.

Kolejne zmiany w Kolegium Redakcyjnym nastąpiły w 2013 r. - powołano wtedy dwóch zastępców redaktora: A. Matczaka i Bogdana Włodarczyka, a do Rady Naukowej dołączyli kolejni członkowie z zagranicy (znalazło się w niej ośmiu cudzoziemców i trzech naukowców z Polski). Śmierć S. Liszewskiego (19402016) - założyciela i wieloletniego redaktora naczelnego - zakończyła pewną epokę w dziejach czasopisma „Turyzm/Tourism”. W 2016 r. redaktorem naczelnym został B. Włodarczyk, a funkcję jego zastępcy objął Andrzej Stasiak. Funkcje redaktorów pełnili wówczas A. Matczak i Sławoj Tanaś.

Obecny skład redakcji ukształtował się w latach 2019-2020. Redaktorem naczelnym został A. Stasiak, jego zastępcą B. Włodarczyk, a w gronie redaktorów znaleźli się: Leszek Butowski, A. Matczak, a także Brigita Žuromskaite z Litwy i Vasyl Kyfjak z Ukrainy. Obowiązki sekretarzy naukowych pełnią Justyna Mokras-Grabowska i Michał Duda, redakcją językową i składem zajmuje się Beata Bednarek (w 2019 r. jeszcze wspólnie z Elżbietą Paradowską). W 2020 r. Rada Naukowa periodyku liczy 27 członków, w tym 18 cudzoziemców, reprezentujących 15 krajów świata.

Oprócz zmian kadrowo-organizacyjnych kluczowe dla rozwoju czasopisma okazało się wdrożenie i wykorzystywanie w codziennej pracy nowoczesnych technologii informatycznych. Od kilku lat „Turyzm/Tourism” dostępny jest na międzynarodowej platformie wydawniczej OJS (Open Journal Systems), a dzięki umowie podpisanej przez Uniwersytet Łódzki z wydawnictwem Elsevier - od 2020 r. również na platformie Digital Commons. W latach 2019-2020 redakcja periodyku brała udział w programie Wsparcie dla czasopism naukowych Ministerstwa Nauki i Szkolnictwa Wyższego. Dzięki uzyskanym funduszom udało się m.in. pozyskać do współpracy wielu uznanych zagranicznych recenzentów. Efektem tych starań było przyjęcie w 2020 r. czasopisma „Turyzm/Tourism” do bazy Scopus. Aktualnie tytuł jest indeksowany w 40 polskich i zagranicznych bazach bibliograficznych. 
Czasopismo „Turyzm/Tourism” w ciągu 35 lat przeszło długą drogę: od pionierskiego periodyku naukowego, w którym publikowane były wyniki pierwszych badań nad turystyką jeszcze w socjalistycznej Polsce (lata 80. XX w.), przez jedno z wiodących w kraju czasopism dokumentujących przeobrażenia turystyki w okresie zmian ustrojowych i gospodarczych (lata 90. XX w., początek XXI w.), po dynamiczny tytuł o zasięgu międzynarodowym, aspirujący do transferowania najnowszej wiedzy o turystyce między Polską a światem (od 2016 r.). „Turyzm/Tourism” - niezmiennie publikowany przez Wydawnictwo Uniwersytetu Łódzkiego, z siedzibą Kolegium Redakcyjnego w Instytucie Geografii Miast, Turyzmu i Geoinformacji UŁ - jest obecnie najstarszym turystycznym czasopismem naukowym w Polsce, o imponującym dorobku publikacyjnym. W latach 1985-2020 wydano drukiem 338 artykuły, 86 notatek naukowych, 87 sprawozdań i 90 recenzji autorstwa wielu wybitnych naukowców polskich i zagranicznych (rys. 2).

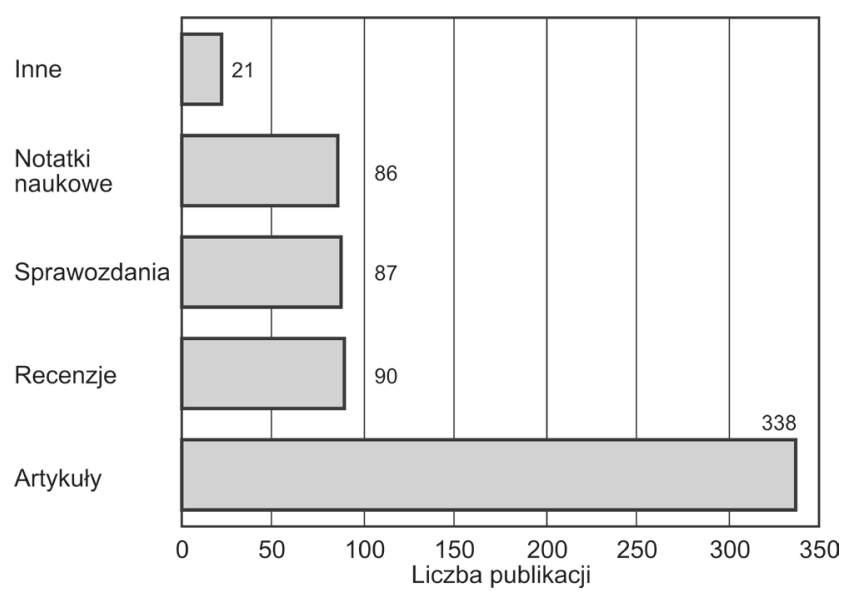

Rysunek 2. Struktura publikacji

w czasopiśmie „Turyzm/Tourism” w latach 1985-2020

Źródło: opracowanie własne

Ale nie liczba prac jest tu ważna, lecz ich jakość. W wielu przypadkach były to dzieła fundamentalne, w których prezentowano wyniki nowatorskich badań, opisywano nowe koncepcje i teorie, podsumowywano osiągnięcia polskich badaczy turyzmu. Należy tu wspomnieć choćby artykuły: J. Fischbacha Funkcja turystyczna jednostek przestrzennych i program jej badania (1989); S. Liszewskiego Spała. Morfologia i funkcja miejscowości wypoczynkowej (1991), Przestrzeń turystyczna (1995), Przestrzeń turystyczna miasta (przykład Łodzi) (1999); S. Liszewskiego i M. Baczwarowa Istota i wtaściwości przestrzeni rekreacyjno-turystycznej (1998); E. Dziegieć Urbanizacja turystyczna terenów wiejskich w Polsce (1995); A. Kowalczyka Turystyka kulinarna - ujeccie geograficzne (2005); M. Jansen-Verbeke Paradygmat terytorialności w turystyce kulturowej (2009); A. Jackowskiego Wkład nauk geograficznych w rozwój wiedzy o turystyce w Polsce (2010). W „Turyzmie” publikowali najwięksi polscy geografowie, ekonomiści, socjologowie i przedstawiciele innych dyscyplin naukowych zajmujących się turystyką.

Kilka zeszytów zostało dedykowanych wybitnym uczonym, którzy położyli istotne zasługi dla rozwoju geografii turyzmu. Byli to: Jadwiga Warszyńska („,Turyzm" 1995), Alicja Krzymowska-Kostrowicka (1999), Bernard Barbier (2002), Antoni Jackowski (2005), Marin Baczwarow (2007), Elżbieta Dziegieć (2009), Stanisław Liszewski (2015), Monika Sławek (2016), Włodzimierz Kurek (2017) oraz Andrzej Matczak (2020). Żegnaliśmy także we Wspomnieniach pośmiertnych twórców ważnych dzieł, koncepcji czy teorii z dziedziny turyzmu, profesorów: Petera Mariota ze Słowacji, Zlatka Pepeonika z Chorwacji, Marina Bachwarowowa (z Bułgarii i Polski), Jadwigę Warszyńska, Krzysztofa Przecławskiego, Ryszarda Gałeckiego i Olafa Rogalewskiego.

Czasopismo stale ewoluowało, dostosowując się do zmian ustrojowych państwa, zarządzeń i wymagań ministerialnych (listy czasopism punktowanych) czy wreszcie postępu w technologiach wydawniczych, edytorskich i drukarskich (od druków offsetowych po wysokospecjalistyczne programy edytorskie i elektroniczne platformy wydawnicze). Niezależnie od zewnętrznych okoliczności zespół redakcyjny nieustannie starał się tworzyć czasopismo na najwyższym możliwym poziomie. Zawsze też mógł liczyć na życzliwe wsparcie Autorów, Recenzentów i Czytelników. Dziękujemy za nie i liczymy, że tak będzie również w przyszłości. Ambitnych celów z pewnością nie zabraknie!

Redakcja czasopisma „Turyzm/Tourism”

\section{BIBLIOGRAFIA}

Dziegieć, E. (1995). Urbanizacja turystyczna terenów wiejskich w Polsce. Turyzm, 5 (1), 5-56.

Fischbach, J. (1989). Funkcja turystyczna jednostek przestrzennych i program jej badania. Acta Universitas Lodzensis. Turyzm, 5, 7-26.

Jackowski, A. (2011). Wkład nauk geograficznych w rozwój wiedzy o turystyce w Polsce. Turyzm/Tourism, 20 (2), 5-36. DOI: https:// doi.org/10.2478/v10106-010-0006-9

Jansen-Verbeke, M. (2009). Paradygmat terytorialności w turystyce kulturowej. Turyzm/Tourism, 19 (1-2), 25-31. DOI: https://doi. org/10.2478/V10106-009-0003-z

Kowalczyk, A. (2005). Turystyka kulinarna - ujęcie geograficzne. Turyzm/Tourism, 15 (1-2), 163-186.

Liszewski, S. (1991). Spała. Morfologia i funkcja miejscowości wypoczynkowej. Turyzm, 1 (2), 5-32.

Liszewski, S. (1995). Przestrzeń turystyczna. Turyzm, 5 (2), 87-103.

Liszewski, S. (1999). Przestrzeń turystyczna miasta (przykład Łodzi). Turyzm, 9 (1), 51-73.

Liszewski, S., Baczwarow, M. (1998). Istota i właściwości przestrzeni rekreacyjno-turystycznej. Turyzm, 8 (1), 39-67.

Warszyńska, J., Jackowski, A. (1987). Podstawy geografii turyzmu. Warszawa: Państwowe Wydawnictwo Naukowe.

Wprowadzenie (1985). Acta Universitatis Lodziensis. Turyzm, 1, 3-4. 